\title{
Nutritional status of year-1 school girls in the Colombo Municipality
}

\author{
L P Paranahewa ${ }^{1}$, L O H W Pathinayake ${ }^{1}$, U S Pathirage ${ }^{1}$
}

Sri Lanka Journal of Child Health, 2002; 31: 82-8

(Key words: Nutritional status, girls, Colombo)

Abstract

Objectives

- To estimate prevalence of malnutrition among year-1 school girls in Colombo Municipality.

- To compare nutritional status of year-1 school girls in 2 grades of schools.

- To study factors which might influence the nutritional status of year-1 school girls.

- To identify ways in which mothers received nutritional advice.

Design A descriptive cross-sectional study.

Setting Schools within Colombo Municipality.

Study population 100 year-1 school girls within Colombo Municipality.

Method 4 schools were selected by random sampling. Stratified sampling was used to determine the number of students to be chosen from each class. Individual children were selected by systematic sampling. Students chronically ill, those whose parents were absent and those born preterm were excluded. An interview-based questionnaire was used to collect data from mothers. Weights and heights of children were measured. The statistical method used to establish significance was the standard normal deviate (Zscore). A Z-score $<1.96$ is not significant ( $\mathrm{p}>0.05)$; $1.96-2.58$ probably significant $(\mathrm{p}<0.05) ;>2.58$ definitely significant $(\mathrm{p}<0,01)$.

Results Overall distribution and separate distribution for each school grade, of heights and weights in year-1 school girls in Colombo Municipality was tabulated and the nutritional status determined. Nutritional status of different grades was compared statistically.

Weights of year-1 school girls were grouped as underweight $(<2 \mathrm{SD})$, normal and overweight $(>2 \mathrm{SD})$ and the values tabulated for factors thought to influence nutritional status.

${ }^{1}$ Medical Student, University of Colombo.

\section{Conclusions}

- $16 \%$ year-1 school girls in Colombo Municipality were underweight and 2\% were stunted.

- There was no significant difference in the nutritional status of year-1 school girls in grades $\mathrm{A}$ and $\mathrm{C}$ schools in the Colombo Municipality.

- None of the factors studied significantly influenced the nutritional status of year-1 school girls in Colombo Municipality.

- 3 commonest modes of receiving nutritional advice were family health midwife, family practitioner and mass media.

\section{Introduction}

Nutritional status of a female is of paramount importance as she is the one capable of giving birth to a child. Nutritional status of a woman in her reproductive age reflects her nutritional level in childhood to a great extent. In Sri Lanka, 16\% children $<5$ years of age are stunted and 30\% are underweight ${ }^{1}$. This motivated us to look into the nutritional status of six year old girls in Sri Lanka. Various factors influence a child's nutrition. Exclusive breast feeding during the first 4 months of life is one such factor. The question has arisen, however, as to whether long duration breast feeding has a positive or negative influence on a child's nutrition ${ }^{2,3}$. Today a woman is often employed compelling her to be out of reach of the family for most of the day. This influences the nutritional status of her children. Studies conducted in Sri Lanka and outside have revealed the importance of socio-economic status, maternal education and birth order of child on nutrition ${ }^{4,5,6}$. Factors which might influence nutritional status, such as weaning, bottle feeding, gap between the previous child and index child, were also included in our study. 


\section{Objectives}

- To estimate prevalence of malnutrition among year-1 school girls in Colombo Municipality.

- To compare nutritional status of year-1 school girls in 2 grades of schools in Colombo Municipality.

- To study factors which influence nutritional status of year-1 school girls.

- To identify ways in which mothers received nutritional advice.

\section{Design}

A descriptive cross-sectional study.

\section{Setting}

4 schools within Colombo Municipality.

\section{Study population}

100 year-1 school girls within Colombo Municipality. Grades A and C schools were taken as representative of 2 social classes and 50 girls from each grade were included in study.

\section{Method}

2 lists of names of schools falling under grades A and $\mathrm{C}$ were obtained from Education Ministry. 2 schools from each list were selected by random sampling. The decided sample size from each grade of school was 50. Stratified sampling was used to decide the number of students to be chosen from each class. Selection of individual children was done using systematic sampling. Every fourth name in the attendance register of each class was marked and the child was included in the study after obtaining mother's consent.

Students who were chronically ill, students whose parents were absent and students who were born preterm were excluded.

Prior permission for data collection was obtained from school principals and dates of parent meetings were obtained from each school. An interviewbased questionnaire was used to collect data from mothers ensuring privacy during interviews. Questions were asked about maternal age, level of maternal and paternal education, maternal occupation currently and during first year of child's life, family income, birth weight, number of children, gap with older child, duration of breast feeding and exclusive breast feeding, weaning, bottle feeding and modes of receiving nutritional advice.
Children were weighed, without shoes, in school uniform, using a bathroom scale which was calibrated accurately. The same person, using same scale weighed all children. After every 5 th child the scale was calibrated to zero.

Height was measured bare footed using a metal tape attached to a straight wall. The same person, using the same tape, measured the height in all children. Another person helped to ensure correct posture of the child.

The overall distribution, and distribution for each grade, of heights and weights in year-1 girls was tabulated and prevalence of malnutrition and stunting determined.

Distribution of heights and weights for each school grade was tabulated and prevalence of malnutrition and stunting determined. They were compared statistically.

Weights of the year-1 school girls were grouped as underweight $(<2 \mathrm{SD}$ NCHS), normal and overweight $(>2 \mathrm{SD}$ NCHS) and the values were tabulated for factors thought to influence nutritional status.

The statistical method used to establish significance was the standard normal deviate (Z-score). Z-score $<1.96$ is not significant $(\mathrm{p}>0.05), 1.96-2.58$ probably significant $(\mathrm{p}<0.05)$ and $>2.58$ definitely significant $(\mathrm{p}<0.01)$

\section{Results and analysis}

Distribution of weight in year-1 school girls in the Colombo Municipality is shown in Table 1.

Table 1

Distribution of weights in year-1 school girls in Colombo Municipality

\begin{tabular}{|c|c|}
\hline Weight range $(\mathrm{kg})$ & No. of school girls \% \\
\hline $11.0-13$ & $06(6)$ \\
\hline $13.1-15$ & $10(10)$ \\
\hline $15.1-17$ & $23(23)$ \\
\hline $17.1-19$ & $27(27)$ \\
\hline $19.1-21$ & $15(15)$ \\
\hline $21.1-23$ & $08(8)$ \\
\hline $23.1-25$ & $04(4)$ \\
\hline $25.1-27$ & $04(4)$ \\
\hline $27.1-29$ & $01(1)$ \\
\hline $29.1-31$ & $02(2)$ \\
\hline Total & $100(100)$ \\
\hline
\end{tabular}

The weights ranged from 11 to $31 \mathrm{~kg}$ with a mean weight of $18.9 \mathrm{~kg}$.

Analysis of weight distribution in the year-1 school girls is shown in Table 2. 
Table 2

Analysis of weight distribution in the year-1 school girls in Colombo Municipality

\begin{tabular}{|c|c|}
\hline Weight $(\mathrm{kg})$ & No. of school girls $\%$ \\
\hline Low & $16(16)$ \\
\hline Normal & $77(77)$ \\
\hline High & $07(7)$ \\
\hline Total & $100(100)$ \\
\hline
\end{tabular}

$16 \%$ year-1 school girls were underweight $(<2 \mathrm{SD})$.

Distribution of heights of year-1 school girls is shown in Table 3.

Table 3

Distribution of heights in year-1 school girls in Colombo Municipality

\begin{tabular}{|c|c|}
\hline Height range (metres) & No. of school girls (\%) \\
\hline $1.00-1.02$ & $03(3)$ \\
\hline $1.03-1.05$ & $04(4)$ \\
\hline $1.06-1.08$ & $09(9)$ \\
\hline $1.09-1.11$ & $15(15)$ \\
\hline $1.12-1.14$ & $25(25)$ \\
\hline $1.15-1.17$ & $15(15)$ \\
\hline $1.18-1.20$ & $13(13)$ \\
\hline $1.21-1.23$ & $03(3)$ \\
\hline $1.24-1.26$ & $11(11)$ \\
\hline $1.27-1.29$ & $02(2)$ \\
\hline Total & $100(100)$ \\
\hline
\end{tabular}

Heights of year-1 school girls ranged from 1.0 to 1.29 metres with a mean of 1.14 metres.

Analysis of height distribution in the year-1 school girls in Colombo Municipality is shown in Table 4.

Table 4

Analysis of height distribution in the year-1 school girls in Colombo Municipality

\begin{tabular}{|c|c|}
\hline Height (metres) & No. of school girls (\%) \\
\hline Low & $02(2)$ \\
\hline Normal & $81(81)$ \\
\hline High & $17(17)$ \\
\hline Total & $100(100)$ \\
\hline
\end{tabular}

$2 \%$ year-1 school girls were stunted $(<2 \mathrm{SD})$.

Distribution of weights in year-1 school girls of grade A schools in Colombo Municipality is shown in Table 5.
Table 5

Distribution of weights in year-1 school girls in grade A schools

\begin{tabular}{|c|c|}
\hline Weight range (kg) & No. of school girls \% \\
\hline $11.0-13$ & $03(6)$ \\
\hline $13.1-15$ & $02(4)$ \\
\hline $15.1-17$ & $04(8)$ \\
\hline $17.1-19$ & $14(28)$ \\
\hline $19.1-21$ & $11(22)$ \\
\hline $21.1-23$ & $08(16)$ \\
\hline $23.1-25$ & $03(6)$ \\
\hline $25.1-27$ & $04(8)$ \\
\hline $27.1-29$ & $00(0)$ \\
\hline $29.1-31$ & $01(2)$ \\
\hline Total & $50(100)$ \\
\hline
\end{tabular}

In grade A schools weights of year-1 school girls ranged from 11 to $31 \mathrm{~kg}$ with a mean of $20.1 \mathrm{~kg}$ and a SD of 4.5 .

Distribution of weights in year-1 school girls of grade $\mathrm{C}$ schools in Colombo Municipality is shown in Table 6.

Table 6

Distribution of weights in year-1 school girls in grade $\mathbf{C}$ schools

\begin{tabular}{|c|c|}
\hline Weight range (kg) & No. of school girls \% \\
\hline $11.0-13$ & $03(6)$ \\
\hline $13.1-15$ & $08(16)$ \\
\hline $15.1-17$ & $19(38)$ \\
\hline $17.1-19$ & $13(26)$ \\
\hline $19.1-21$ & $04(8)$ \\
\hline $21.1-23$ & $00(0)$ \\
\hline $23.1-25$ & $01(2)$ \\
\hline $25.1-27$ & $00(0)$ \\
\hline $27.1-29$ & $01(2)$ \\
\hline $29.1-31$ & $01(2)$ \\
\hline Total & $50(100)$ \\
\hline
\end{tabular}

In grade $\mathrm{C}$ schools weights of year-1 school girls ranged from 11 to $31 \mathrm{~kg}$ with a mean of $17.7 \mathrm{~kg}$ and a SD of 4.7 .

The mean weight in grade A schools was significantly greater than that in grade $\mathrm{C}$ schools (Z-score 2.82; $<<0.01$ ).

Analysis of weight distribution in the year-1 school girls of grade A schools is shown in Table 7. 
Table 7

Analysis of weight distribution in the year-1 school girls in grade A schools

\begin{tabular}{|c|c|}
\hline Weight $(\mathrm{kg})$ & No. of school girls (\%) \\
\hline Low & $05(10)$ \\
\hline Normal & $41(82)$ \\
\hline High & $04(08)$ \\
\hline Total & $50(100)$ \\
\hline
\end{tabular}

$10 \%$ year-1 school girls in grade A schools were underweight.

Analysis of weight distribution in the year-1 school girls of grade $\mathrm{C}$ schools is shown in Table 8.

Table 8

Analysis of weight distribution in the year-1 school girls in grade $\mathbf{C}$ schools

\begin{tabular}{|c|c|}
\hline Weight $(\mathrm{kg})$ & No. of school girls (\%) \\
\hline Low & $11(22)$ \\
\hline Normal & $36(72)$ \\
\hline High & $03(6)$ \\
\hline Total & $50(100)$ \\
\hline
\end{tabular}

$22 \%$ year-1 school girls in grade $\mathrm{C}$ schools were underweight.

$10 \%$ year-1 school girls in grade A schools were underweight compared with $22 \%$ in grade $\mathrm{C}$ schools. This is not statistically significant (Z-score $1.66 ; \mathrm{p}>0.05$ ).

Distribution of heights in year-1 school girls of grade A schools is shown in Table 9.

Table 9

Distribution of heights in year-1 school girls in grade A schools

\begin{tabular}{|c|c|}
\hline Height range (metres) & No. of school girls (\%) \\
\hline $1.00-1.02$ & $00(0)$ \\
\hline $1.03-1.05$ & $01(2)$ \\
\hline $1.06-1.08$ & $01(2)$ \\
\hline $1.09-1.11$ & $04(8)$ \\
\hline $1.12-1.14$ & $13(26)$ \\
\hline $1.15-1.17$ & $10(20)$ \\
\hline $1.18-1.20$ & $08(16)$ \\
\hline $1.21-1.23$ & $03(6)$ \\
\hline $1.24-1.26$ & $09(18)$ \\
\hline $1.27-1.29$ & $01(2)$ \\
\hline Total & $50(100)$ \\
\hline
\end{tabular}

In grade A schools, heights of year-1 school girls ranged from 1.04 to 1.29 metres with a mean of 1.17 metres and a SD of 0.054 .

Distribution of heights of year-1 school girls of grade C schools is shown in Table 10.
Table 10

Distribution of heights in year-1 school girls in grade $\mathbf{C}$ schools

\begin{tabular}{|c|c|}
\hline Height range (metres) & No. of school girls (\%) \\
\hline $1.00-1.02$ & $03(6)$ \\
\hline $1.03-1.05$ & $03(6)$ \\
\hline $1.06-1.08$ & $08(16)$ \\
\hline $1.09-1.11$ & $11(22)$ \\
\hline $1.12-1.14$ & $12(24)$ \\
\hline $1.15-1.17$ & $05(10)$ \\
\hline $1.18-1.20$ & $05(10)$ \\
\hline $1.21-1.23$ & $00(0)$ \\
\hline $1.24-1.26$ & $02(4)$ \\
\hline $1.27-1.29$ & $01(2)$ \\
\hline Total & $50(100)$ \\
\hline
\end{tabular}

In grade $\mathrm{C}$ schools, heights of year-1 school girls ranged from 1.00 to 1.28 metres with a mean of 1.17 metres and a SD of 0.054 .

The mean heights in grades $\mathrm{A}$ and $\mathrm{C}$ schools were identical.

Variation of nutritional status with maternal age is shown in Table 11.

Table 11

Maternal age and nutritional status (wt/age)

\begin{tabular}{|c|c|c|c|c|}
\hline $\begin{array}{l}\text { Maternal } \\
\text { age (yrs) }\end{array}$ & $\begin{array}{l}\text { Wt }< \\
\text { normal }\end{array}$ & $\begin{array}{l}\text { Wt } \\
\text { normal }\end{array}$ & $\begin{array}{l}\text { Wt> } \\
\text { normal }\end{array}$ & Total \\
\hline $20-34$ & 09 & 33 & 03 & 45 \\
\hline 35 or $>$ & 07 & 44 & 04 & 55 \\
\hline Total & 16 & 77 & 07 & 100 \\
\hline
\end{tabular}

$20 \%$ mothers $<35$ years of age had underweight year-1 school girls compared with $13 \%$ mothers 35 years or older ( $Z$-score $0.93 ; \mathrm{p}>0.05$ ).

Variation of nutritional status with maternal educational level is shown in Table 12.

Table 12

Maternal educational level and nutritional status (wt/age)

\begin{tabular}{|c|c|c|c|c|}
\hline $\begin{array}{c}\text { Maternal } \\
\text { educational } \\
\text { level }\end{array}$ & $\begin{array}{l}\text { Wt }< \\
\text { normal }\end{array}$ & $\begin{array}{l}\text { Wt } \\
\text { normal }\end{array}$ & $\begin{array}{l}\text { Wt }> \\
\text { normal }\end{array}$ & Total \\
\hline$<\mathrm{O} / \mathrm{L}$ & 5 & 21 & 1 & 27 \\
\hline $\mathrm{O} / \mathrm{L}$ or $>$ & 11 & 56 & 6 & 73 \\
\hline Total & 16 & 77 & 07 & 100 \\
\hline
\end{tabular}

$19 \%$ mothers who were educated $<\mathrm{O} / \mathrm{L}$ had underweight year-1 school girls compared to $15 \%$ mothers with higher educational qualifications (Zscore $0.58 ; \mathrm{p}>0.05$ ). 
Variation of nutritional status with paternal educational level is shown in Table 13.

Table 13

Paternal educational level and nutritional status (wt/age)

\begin{tabular}{|c|c|c|c|c|}
\hline $\begin{array}{c}\text { Paternal } \\
\text { educational } \\
\text { level }\end{array}$ & $\begin{array}{l}\text { Wt }< \\
\text { normal }\end{array}$ & $\begin{array}{l}\text { Wt } \\
\text { normal }\end{array}$ & $\begin{array}{l}\text { Wt }> \\
\text { normal }\end{array}$ & Total \\
\hline$<\mathrm{O} / \mathrm{L}$ & 04 & 17 & 01 & 22 \\
\hline $\mathrm{O} / \mathrm{L}$ or $>$ & 12 & 60 & 06 & 78 \\
\hline Total & 16 & 77 & 07 & 100 \\
\hline
\end{tabular}

$18 \%$ fathers who were not educated up to $<\mathrm{O} / \mathrm{L}$ had underweight year-1 school girls compared to $15 \%$ better educated fathers ( $Z$-score $0.33 ; \mathrm{p}>0.05$ ).

Variation of nutritional status with maternal occupation is shown in Table 14.

Table 14

Maternal occupation and nutritional status (wt/age)

\begin{tabular}{|c|c|c|c|c|}
\hline $\begin{array}{c}\text { Currently } \\
\text { employed }\end{array}$ & $\begin{array}{l}\text { Wt } \\
\text { normal }\end{array}$ & $\begin{array}{l}\text { Wt } \\
\text { normal }\end{array}$ & $\begin{array}{l}\text { Wt }> \\
\text { normal }\end{array}$ & Total \\
\hline Yes & 05 & 32 & 03 & 40 \\
\hline No & 11 & 45 & 04 & 60 \\
\hline Total & 16 & 77 & 07 & 100 \\
\hline
\end{tabular}

$13 \%$ currently employed mothers had underweight year-1 school girls compared to $18 \%$ currently unemployed mothers (Z-score $0.69 ; \mathrm{p}>0.05$ ).

Variation of nutritional status with maternal occupation during first year is shown in Table 15.

Table 15

Maternal occupation during first year and nutritional status (wt/age)

\begin{tabular}{|c|c|c|c|c|}
\hline $\begin{array}{c}\text { Employed } \\
\text { 1st year }\end{array}$ & $\begin{array}{l}\text { Wt } \\
\text { normal }\end{array}$ & $\begin{array}{l}\text { Wt } \\
\text { normal }\end{array}$ & $\begin{array}{l}\text { Wt> } \\
\text { normal }\end{array}$ & Total \\
\hline Yes & 13 & 54 & 03 & 67 \\
\hline No & 03 & 23 & 04 & 33 \\
\hline Total & 16 & 77 & 07 & 100 \\
\hline
\end{tabular}

$19 \%$ mothers who were not employed in the first year after delivery had underweight year-1 school girls compared with $9 \%$ mothers who were employed during this period (Z-score 1.44; $\mathrm{p}>0.05$ ).

Variation of nutritional status with family income is shown in Table 16
Table 16

Family income and nutritional status

(wt/age)

\begin{tabular}{|c|c|c|c|c|}
\hline $\begin{array}{c}\text { Income } \\
\text { month } \\
(R s)\end{array}$ & $\begin{array}{l}\text { Wt }< \\
\text { normal }\end{array}$ & $\begin{array}{l}\text { Wt } \\
\text { normal }\end{array}$ & $\begin{array}{l}\text { Wt }> \\
\text { normal }\end{array}$ & Total \\
\hline$<5000$ & 02 & 14 & 01 & 17 \\
\hline 5000 or $>$ & 14 & 63 & 06 & 83 \\
\hline Total & 16 & 77 & 07 & 100 \\
\hline
\end{tabular}

$12 \%$ year-1 school girls with a monthly family income of $<$ Rs. 5000 were underweight compared to $17 \%$ with a family income of Rs. 5000 or more. (Z-score $0.56 ; \mathrm{p}>0.05$ ).

Variation of nutritional status with birth weight is shown in Table 17.

Table 17

Birth weight and nutritional status (wt/age)

\begin{tabular}{|c|c|c|c|c|}
\hline $\begin{array}{c}\text { Birth wt } \\
(\mathrm{kg})\end{array}$ & $\begin{array}{l}\text { Wt } \\
\text { normal }\end{array}$ & $\begin{array}{l}\text { Wt } \\
\text { normal }\end{array}$ & $\begin{array}{l}\text { Wt }> \\
\text { normal }\end{array}$ & Total \\
\hline$<2.5$ & 05 & 21 & 01 & 27 \\
\hline 2.5 or $>$ & 09 & 49 & 04 & 62 \\
\hline Total & 14 & 70 & 05 & $89 *$ \\
\hline
\end{tabular}

*Children who were premature were excluded

$19 \%$ year-1 school girls who had birth weights $<2.5$ $\mathrm{kg}$ and $12 \%$ with birth weights $2.5 \mathrm{~kg}$ or more were found to be underweight (Z-score $0.81 ; \mathrm{p}>0.05$ ).

Variation of nutritional status with number of children in family is shown in Table 18.

Table 18

Total number of children in the family and nutritional status (wt/age)

\begin{tabular}{|c|c|c|c|c|}
\hline $\begin{array}{c}\text { No. of } \\
\text { children }\end{array}$ & $\begin{array}{l}\text { Wt } \\
\text { normal }\end{array}$ & $\begin{array}{l}\text { Wt } \\
\text { normal }\end{array}$ & $\begin{array}{l}\text { Wt }> \\
\text { normal }\end{array}$ & Total \\
\hline$<3$ & 14 & 60 & 06 & 80 \\
\hline 3 or $>$ & 02 & 17 & 01 & 20 \\
\hline Total & 16 & 77 & 07 & 100 \\
\hline
\end{tabular}

$10 \%$ year- 1 school girls who had 3 or more siblings were underweight compared to $18 \%$ who had 2 or less siblings. (Z-score 1.03; $\mathrm{p}>0.05$ ).

Variation of nutritional status with the gap with the older child is shown in Table 19.

Table 19

Gap with older child and nutritional status (wt/age)

\begin{tabular}{|c|c|c|c|c|}
\hline $\begin{array}{c}\text { Gap } \\
\text { (months) }\end{array}$ & $\begin{array}{l}\text { Wt } \\
\text { normal }\end{array}$ & $\begin{array}{l}\text { Wt } \\
\text { normal }\end{array}$ & $\begin{array}{l}\text { Wt }> \\
\text { normal }\end{array}$ & Total \\
\hline 36 or $>$ & 08 & 56 & 06 & 70 \\
\hline$<36$ & 08 & 21 & 01 & 30 \\
\hline Total & 16 & 77 & 07 & 100 \\
\hline
\end{tabular}


$11 \%$ year-1 school girls with a gap of 36 months or more with older sibling were underweight compared to $27 \%$ with a gap of $<36$ months (Zscore $0.79 ; \mathrm{p}>0.05)$.

Variation of nutritional status with the duration of breast feeding is shown in Table 20 .

Table 20

Duration of breast feeding and nutritional status (wt/age)

\begin{tabular}{|c|c|c|c|c|}
\hline $\begin{array}{l}\text { Duration } \\
\text { (months) }\end{array}$ & $\begin{array}{l}\text { Wt } \\
\text { normal }\end{array}$ & $\begin{array}{l}\text { Wt } \\
\text { normal }\end{array}$ & $\begin{array}{l}\text { Wt }> \\
\text { normal }\end{array}$ & Total \\
\hline$<8$ & $6(38)$ & $18(23)$ & $2(29)$ & 26 \\
\hline 8 or $>$ & $10(62)$ & $59(77)$ & $5(71)$ & 74 \\
\hline Total & $16(100)$ & $77(100)$ & $7(100)$ & 100 \\
\hline
\end{tabular}

$14 \%$ year-1 school girls, breast fed for 8 months or more were underweight compared to $23 \%$ breast fed for less than 8 months ( $Z$-score $0.98 ; \mathrm{p}>0.05$ ).

Variation of nutritional status with the duration of exclusive breast feeding is shown in Table 21 .

Table 21

Duration of exclusive breast feeding and nutritional status (wt/age)

\begin{tabular}{|c|c|c|c|c|}
\hline $\begin{array}{l}\text { Duration } \\
\text { (months) }\end{array}$ & $\begin{array}{l}\text { Wt }< \\
\text { normal }\end{array}$ & $\begin{array}{l}\text { Wt } \\
\text { normal }\end{array}$ & $\begin{array}{l}\text { Wt }> \\
\text { normal }\end{array}$ & Total \\
\hline$<4$ & 09 & 33 & 01 & 43 \\
\hline 4 or $>$ & 07 & 44 & 06 & 57 \\
\hline Total & 16 & 77 & 07 & 100 \\
\hline
\end{tabular}

$12 \%$ year-1 school girls, who were exclusively breast fed for 4 months or $>$ were underweight compared to $21 \%$ exclusively breast fed for $<4$ months (Z-score 1.2; $\mathrm{p}>0.05$ ).

Variation of nutritional status with the start of weaning is shown in Table 22.

Table 22

Commencement of weaning and nutritional status (wt/age)

\begin{tabular}{|c|c|c|c|c|}
\hline $\begin{array}{l}\text { Duration } \\
\text { (months) }\end{array}$ & $\begin{array}{l}\text { Wt } \\
\text { normal }\end{array}$ & $\begin{array}{l}\text { Wt } \\
\text { normal }\end{array}$ & $\begin{array}{l}\text { Wt }> \\
\text { normal }\end{array}$ & Total \\
\hline$<4$ & 07 & 19 & 01 & 27 \\
\hline 4 or $>$ & 09 & 58 & 06 & 73 \\
\hline Total & 16 & 77 & 07 & 100 \\
\hline
\end{tabular}

$26 \%$ year-1 school girls, who were weaned $<4$ months were underweight compared to $12 \%$ who were weaned at or after 4 months (Z-score 1.52; $\mathrm{p}>0.05)$.

Variation of nutritional status with bottle feeding is shown in Table 23.
Table 23

Bottle feeding and nutritional status (wt/age)

\begin{tabular}{|c|c|c|c|c|}
\hline $\begin{array}{c}\text { Bottle } \\
\text { feeding }\end{array}$ & $\begin{array}{l}\text { Wt }< \\
\text { normal }\end{array}$ & $\begin{array}{l}\text { Wt } \\
\text { normal }\end{array}$ & $\begin{array}{l}\text { Wt }> \\
\text { normal }\end{array}$ & Total \\
\hline Never & 03 & 24 & 02 & 29 \\
\hline $\begin{array}{c}4 \text { mths or } \\
>\end{array}$ & 11 & 45 & 05 & 61 \\
\hline$<4$ mths & 02 & 08 & 00 & 10 \\
\hline Total & 16 & 77 & 07 & 100 \\
\hline
\end{tabular}

$20 \%$ year-1 school girls, who were bottle fed before the 4th month, were underweight, compared to $18 \%$ who were never bottle fed or bottle fed at or after 4 months (Z-score 1.15; $\mathrm{p}>0.05$ ).

Modes of receiving nutritional advice is shown in Table 24.

Table 24

Modes of receiving nutritional advice

\begin{tabular}{|c|c|}
\hline Mode & \% of mothers \\
\hline Specialist opinion & 23 \\
\hline Family practitioner & 38 \\
\hline TV/Radio & 31 \\
\hline Newspapers/Magazines & 22 \\
\hline Family Health midwife & 49 \\
\hline Others & 10 \\
\hline Total & $100^{*}$ \\
\hline
\end{tabular}

* More than one response was allowed

The commonest mode of receiving nutritional advice among mothers of Colombo Municipality was through the Family Health Midwife (49). Other common modes were the family practitioner (38) and mass media. (31).

\section{Discussion}

In the demographic and health surveys conducted in 1987 and $199363 \%$ of children $<5$ years of age were found to have protein energy malnutrition while $72 \%$ of 5 year old children in Sri Lanka were found to be underweight ${ }^{7}$.

Weights of year-1 school girls in Colombo Municipality showed a normal distribution which was shifted $0.564 \mathrm{SD}$ to the left from reference NCHS population. 16\% year-1 school girls were underweight $(<2 \mathrm{SD})$ compared to $30 \%$ in Sri Lanka ${ }^{1}$.

The heights of year-1 school girls in Colombo Municipality showed a normal distribution. There was no significant difference of height compared with the NCHS reference population. 2\% year-1 school girls were stunted $(<2 \mathrm{SD})$ compared to $16 \%$ in Sri Lanka ${ }^{1}$. 
The weights of year-1 school girls in both grades A and $\mathrm{C}$ schools showed a normal distribution. The weight distribution curve of grade $\mathrm{C}$ schools showed a 1.05 SD shift to the left from the NCHS reference population. The mean weight in grade A schools was significantly greater than in grade $\mathrm{C}$ schools (Z-score 2.82; $\mathrm{p}<0.01)$. However the difference in nutritional status of grade $\mathrm{A}$ and $\mathrm{C}$ schools was not statistically significant (Z-score $1.66 ; \mathrm{p}>0.05)$.

The heights of the year-1 school girls in grades A and $\mathrm{C}$ schools showed a normal distribution. The mean heights of year-1 school girls in grade A and C schools were identical.

The maternal age, maternal level of education, paternal level of education, current employment of the mother, maternal employment during the first year after delivery, family income, low birth weight, number of siblings, gap with older sibling, duration of exclusive breast feeding, prolonged breast feeding, time of weaning did not significantly influence the nutritional status of year-1 school girls in Colombo Municipality.

\section{Conclusions}

- $16 \%$ year-1 school girls in Colombo Municipality were underweight and $2 \%$ were stunted.

- There was no significant difference in the nutritional status of year-1 school girls in grades $\mathrm{A}$ and $\mathrm{C}$ schools in the Colombo Municipality.

- None of the factors studied significantly influenced the nutritional status of year-1 school girls in Colombo Municipality.

- 3 commonest modes of receiving nutritional advice were family health midwife, family practitioner and mass media.

\section{Acknowledgements}

We thank Prof. Dulitha Fernando, Dr. Mrs. Nalika Gunawardhana, the staff of the Department of Community Medicine, Principals and staffs of Visakha Vidyalaya, Sirimavo Bandaranayake Balika Vidyalaya, Anuruddha Balika Vidyalaya, and Rathnavalee Balika Vidyalaya, Librarian and staff of the Medical Faculty library, Family Health Bureau, Health Education Bureau, Sajika and Hasini Gallege, all the par ticipants of the study and their parents for their invaluable help.

\section{References}

1. WHO. Nutrition in South East Asia. 2000: 9-10.

2. Onyango A W, Esrey S A, Kramer M S. Continued breast feeding and child growth in the second year of life. A prospective cohort study in western Kenya. Lancet 1999; 354: 2041-5.

3. Fawzi W W, Herrera M G, Nestel P. A longitudinal study of prolonged breast feeding in relation to child undernutrition. International Journal of Epidemiology 1998; 27 (2): 225-60.

4. Begin F, Habicht JP, Frongillo EA. The deterioration in children's nutritional status in rural Chad: The effect of mother's influence on feeding. American Journal of Public Health 1997; 87 (8): 1356-9.

5. Crooks D L. Child growth and nutritional status in a high poverty community in eastern Kentucky. American Journal of Physiology and Anthropology 1999; 109 (1): 129-42.

6. Reed B A, Habicht J P, Niameogo C. The effects of maternal education on child nutritional status depending on socioenvironmental conditions. International Journal of Epidemiology 1996; 25 (3): 585 92.

7. Gunasekera HR. Nutritional status of children in Sri Lanka. DHS surveys 1996; 1: 9-10. 